\section{Time to get clean}

\section{Formal recognition of drug pollution will help to protect humans and ecosystems.}

$\mathrm{M}$ ost nations have strict controls on environmental waste, from arsenic to zinc. Yet no legal limits have been set to control pollution from drugs during their manufacture, use and disposal. That is despite evidence that pharmaceutical waste can wreak havoc in the environment - hormones found in contraceptives cause male fish to grow female sex organs, and a painkiller used in livestock has wiped out millions of vultures in India that fed on the carcasses.

The need for global action was recognized internationally for the first time last week at a meeting in Geneva, Switzerland, led by the United Nations Environment Programme. The move is a small but significant development.

Pharmaceuticals pollute the environment mainly because wastewater treatment plants do not adequately remove compounds found in the drugs that people ingest and excrete. High concentrations are also released into water during drug manufacture. Other pollution comes from unused medicines that have not been safely disposed of, particularly in developing countries where stockpiles of outdated donated medicines can build up and leach into the environment. The industry points to studies that find pharmaceutical pollution does not pose an immediate risk to human health, because the concentrations in drinking water are not high enough to cause problems. But the levels found in the environment still damage wildlife and ecosystems.

Last week, countries, the drug industry and non-governmental bodies formally agreed - for the first time - that humans and ecosystems need protection from pharmaceutical pollution. A resolution passed at the triennial International Conference on Chemicals Management
(ICCM) also backs the need for global cooperation to build awareness and push for action to address drug pollution. The deal puts the issue permanently on the ICCM's radar, and is a crucial first step towards building much-needed initiatives to address the problem.

The ICCM is a middleweight organization with high-level backing, and so it is able to make an impact. A large part of its remit is to keep an eye on progress towards a voluntary goal to ensure that, by 2020 , chemicals are used and produced in a way that minimizes ill effects on human health and the environment. Heads of state backed the goal in 2002. It has helped to implement national bans on the use of lead in paint in developing countries including Uruguay and Nepal.

Critics will say that the latest pledge is weak - and they are correct. It rejects specific actions to combat the problem, as had been proposed by the governments of Peru and Uruguay and by the International Society of Doctors for the Environment. There are no commitments to a network of scientists and experts to research and share knowledge, or to improve national bio-monitoring. And there are no new legal demands on drug firms to clean up their manufacturing processes.

Although drug companies say that they maintain good environmental practices, research shows that drug manufacture is a significant source of pharmaceutical pollution. For example, unpublished data from the US Geological Survey show that concentrations of certain drugs are up to five times higher in the effluents of wastewater-treatment plants that serve drug-manufacturing facilities compared with those that do not.

The powerful pharmaceutical and water industries, which fear expensive measures to help to address the problem, have already demonstrated their muscle. Through aggressive lobbying, they managed to derail European efforts to impose legal environmental limits on two drugs in 2012.

The ICCM agreement should help to change things. With the world's eyes now on this issue, industry groups and lobbyists will find it harder to bend initiatives in their favour. There could be an early test of the resolution: European policymakers plan to publish a strategy to tackle drug pollution in the region's waterways by the end of the year.

\section{Optimistic outlook}

\begin{abstract}
In difficult times, Turkey is investing in a clutch of new scientific research centres.
\end{abstract}

$\mathrm{T}$ The airy, architecturally striking building that is the brand-new Izmir Biomedicine and Genome Center (iBG) could have been anywhere in Europe. But when Turkey's science minister, Fikri Işik, turned up to speak at its inaugural ceremony last month (see page 171), surrounded by an ostentatious swarm of dark-clad security guards, the cultural differences were apparent.

Turkey, with its toe-hold on the European continent and a landmass stretching nearly 2,000 kilometres to borders with Syria, Iraq, Iran, Georgia and Armenia, is familiar with difference. Mediterranean cities such as Istanbul and Izmir are westernized, but eastern cities are conservatively Islamic and the southeast is plagued by violence rooted in cross-border Kurdish separatist movements.

Politicians everywhere view the country as a potential bridge between the West and the war-torn Middle East, but some Turks fear that renewed Kurdish conflicts could degenerate into civil war. They fear also that the national election in three weeks will see president Recep Tayyip Erdoğan change the constitution to give himself still more power.

Can science thrive in this environment? Erdoğan has blurred the constitutional separation of state and religion. Under his regime, scientists have witnessed state-condoned rejection of Darwinism and imprisonment of academics on trumped-up terrorism charges.

There are some positive signs, however. Turkey's negotiations with the European Union for membership stalled after troops violently dispersed political protestors in Istanbul's Taksim Square in 2013, yet the country continues to align its science policies with those of the EU. Accordingly, last year it passed two laws to improve and expand the research environment in strategic areas.

One law creates a slew of institutes across the country, some of which will provide regional services such as genome sequencing to ill-equipped universities. Others will be national research centres which, like the iBG, will aspire to carry out internationally competitive research and successfully compete to host major EU research facilities. Along with the advantage of secure funding, the national research centres will operate under new rules. They will be relatively free to manage their operations and budgets - a sign that the government recognizes that it should not micromanage research if it wants it to thrive.

The other law creates a Turkish National Institutes of Health, which will comprise 6 institutes, with the creation of 400 jobs in science.

All of these new centres must be allowed to develop free from political interference - scientists are particularly concerned that the government will seek close control over the health institutes.

Researchers in other Middle Eastern countries often find it simpler to collaborate with Turkish scientists than with westerners - travel is cheaper and usually visa-free. An improved scientific environ-
DNATURE.COM To comment online, click on Editorials at: go.nature.com/xhunqv ment in Turkey may serve as the desired bridge, creating an intellectual network that can continue to converse, whatever the political tensions. Science can, in its limited way, be a force for peace. 